\title{
Fluoroscopic lumbar interlaminar epidural injections in managing chronic lumbar axial or discogenic pain
}

This article was published in the following Dove Press journal:

Journal of Pain Research

23 August 2012

Number of times this article has been viewed

\author{
Laxmaiah Manchikanti ${ }^{1,2}$ \\ Kimberly A Cash' \\ Carla D McManus' \\ Vidyasagar Pampati' \\ Ramsin Benyamin ${ }^{3,4}$
}

'Pain Management Center of Paducah, Paducah, KY; ${ }^{2}$ University of Louisville, Louisville, KY; ${ }^{3}$ Millennium Pain

Center, Bloomington, IL; ${ }^{4}$ University of Illinois, Urbana-Champaign, IL, USA
Correspondence: Laxmaiah Manchikanti 283I Lone Oak Road, Paducah, KY 42003, USA

Tel +I 2705548373 ext I0 I

Fax +l 2705548987

Email drIm@thepainmd.com
Abstract: Among the multiple causes of chronic low back pain, axial and discogenic pain are common. Various modalities of treatments are utilized in managing discogenic and axial low back pain including epidural injections. However, there is a paucity of evidence regarding the effectiveness, indications, and medical necessity of any treatment modality utilized for managing axial or discogenic pain, including epidural injections. In an interventional pain management practice in the US, a randomized, double-blind, active control trial was conducted. The objective was to assess the effectiveness of lumbar interlaminar epidural injections of local anesthetic with or without steroids for managing chronic low back pain of discogenic origin. However, disc herniation, radiculitis, facet joint pain, or sacroiliac joint pain were excluded. Two groups of patients were studied, with 60 patients in each group receiving either local anesthetic only or local anesthetic mixed with non-particulate betamethasone. Primary outcome measures included the pain relief-assessed by numeric rating scale of pain and functional status assessed by the, Oswestry Disability Index, Secondary outcome measurements included employment status, and opioid intake. Significant improvement or success was defined as at least a $50 \%$ decrease in pain and disability. Significant improvement was seen in $77 \%$ of the patients in Group I and $67 \%$ of the patients in Group II. In the successful groups (those with at least 3 weeks of relief with the first two procedures), the improvement was $84 \%$ in Group I and $71 \%$ in Group II. For those with chronic function-limiting low back pain refractory to conservative management, it is concluded that lumbar interlaminar epidural injections of local anesthetic with or without steroids may be an effective modality for managing chronic axial or discogenic pain. This treatment appears to be effective for those who have had facet joints as well as sacroiliac joints eliminated as the pain source.

Keywords: lumbar disc herniation, axial or discogenic pain, lumbar interlaminar epidural injections, local anesthetic, steroids, controlled comparative local anesthetic blocks, NCT00681447

\section{Introduction}

Epidural injections are one of the most commonly utilized treatment modalities for managing chronic low back pain with or without lower extremity pain. ${ }^{1-12}$ Despite increasing utilization of lumbar epidural injections, significant debate continues regarding their effectiveness, specifically any conditions other than disc herniation and compressive radiculitis. The pathophysiology of low back pain and radicular pain is the subject of ongoing research and controversy, with discogenic pain assuming a major role as a cause of non-specific low back pain, beyond disc herniation. ${ }^{13-16}$ In fact, soon after the description of intervertebral disc herniation by Mixter and Barr ${ }^{17}$ in American medical literature in 1934 with their landmark description of the herniated nucleus pulposus, 
Mixter and Ayers ${ }^{18}$ showed that radicular pain can occur without disc herniation. Further, non-specific low back pain constitutes $80 \%$ or $90 \%$ of low back pain without identifiable causes with a large proportion having chronic axial low back pain secondary to progressive degenerative disc disease..$^{2,19-22}$ It has been shown that discs have innervation with deep ingrowth into degenerated intervertebral discs. ${ }^{23-26}$ Animal models have identified upregulation of various molecules such as calcitonin gene-related peptide and substance $\mathrm{P}$ in dorsal root ganglion neurons innervating degenerated intervertebral discs. ${ }^{27,28}$ Research also has detected high levels of inflammatory mediators in degenerated discs. While the majority of patients with axial low back pain improve with conservative management, various types of interventions have been described for chronic patients, but most interventions are highly variable and are associated with poor outcomes. ${ }^{29-40}$

In the past, all axial pain was attributed to disc degeneration. However, the development of controlled diagnostic blocks, and interventional techniques including discography, facet joint blocks, and sacroiliac joint blocks, have provided evidence that axial pain can also be caused by facet joints and sacroiliac joints. Utilizing provocation discography, the prevalence of pain due to internal disc disruption was reported to be $39 \%$ in patients suffering with chronic low back pain, ${ }^{41}$ whereas primary discogenic pain was reported in $26 \%{ }^{42}$ when no other cause was suspected. In addition, facet joint pain has been shown to be present in $21 \%-41 \%$ of patients, ${ }^{43}$ whereas sacroiliac joint pain has been established in $10 \%-38 \%$ of a selected population. ${ }^{44}$

The underlying mechanism of action for epidurally administered local anesthetic and steroids has been described, though not well understood. However, historically it has been believed that epidural steroids function by reducing inflammation, thus limiting the indications to compressive radiculopathy or, at best, radiculitis secondary to chemical irritation. Much of the literature on lumbar interlaminar epidurals has been negative except in recent years when fluoroscopic guidance was utilized..$^{39,45-53}$ A variation of lumbar interlaminar injections, caudal epidural injections, have also been proven to be effective in multiple causes of low back pain with or without lower extremity pain. ${ }^{38,48,54-57}$ Recent evidence also has demonstrated effectiveness for fluoroscopically administered epidural injections in the cervical spine ${ }^{58-61}$ as well as the thoracic spine. ${ }^{62}$ These evaluations have illustrated the effectiveness of epidural injections not only for disc herniation, but also for axial or discogenic pain after eliminating facet and sacroiliac joint pain, spinal stenosis, and post-surgery syndrome. In fact, in the published preliminary results of the current study, lumbar interlaminar epidural injections provided improvement in $74 \%$ of patients who received local anesthetic only, and $63 \%$ in the group who received local anesthetic and steroids. ${ }^{39}$

The current report evaluates the role of lumbar interlaminar epidural injections for patients with chronic axial or discogenic low back pain in 120 patients with a 1 -year follow-up. ${ }^{39}$

\section{Methods}

This active control, randomized, double-blind trial was conducted in an interventional pain management practice, in a specialty referral center, with approval of the Institutional Review Board (IRB). It follows Consolidated Standards of Reporting Trials (CONSORT) guidelines. ${ }^{63}$ The study is registered with the US Clinical Trial Registry with an assigned number of NCT00681447.

The internal resources of the practice were used to conduct the study. There was no external funding, either from industry or from elsewhere.

\section{Interventions}

Patients were assigned into one of two groups. Group I patients received lumbar interlaminar epidural injections with $6 \mathrm{~mL}$ of lidocaine $0.5 \%$ preservative free; Group II patients received lumbar interlaminar epidural injections with $5 \mathrm{~mL}$ of lidocaine $0.5 \%$ preservative-free mixed with $6 \mathrm{mg}$ or $1 \mathrm{~mL}$ of non-particulate betamethasone.

\section{Participants}

All patients were recruited from new patients presenting to the center who met the inclusion criteria. The IRB-approved protocol and informed consent, which described in detail all aspects of the study and its process, were provided to all participating patients.

\section{Pre-enrollment data collection}

The data collected included Numeric Rating Scale (NRS) for pain, Oswestry Disability Index 2.0 (ODI) for functional status, medical and surgical history of any co-existing disease(s), radiologic investigations, physical examination, work status, and opioid intake.

\section{Inclusion criteria}

Inclusion criteria included only the patients with a diagnosis of lumbar axial or discogenic pain; over the age of 18 years; a history of chronic function-limiting low back pain of at least 6 months duration; and the ability to understand the study protocol and provide voluntary, written informed consent, and participate in outcome measurements. 
Additional criteria were a failure to improve with conservative management, including, but not limited to, physical therapy, chiropractic manipulation, exercises, drug therapy, and bedrest.

Exclusion criteria were a positive response for lumbar facet joint or sacroiliac joint pain by means of controlled, comparative local anesthetic blocks; previous lumbar surgery; uncontrollable or unstable opioid use; uncontrolled psychiatric disorders; uncontrolled medical illness, either acute or chronic; any conditions that could interfere with the interpretation of the outcome assessments; pregnant or lactating women; and a history or potential for adverse reaction(s) to local anesthetics or steroids.

\section{Description of interventions}

All participating patients were evaluated with controlled, comparative local anesthetic lumbar facet joint nerve blocks or sacroiliac joint injections. The process started with diagnostic facet joint nerve blocks with $0.5 \mathrm{~mL}$ of $1 \%$ lidocaine, followed by the blockade of facet joint nerves with $0.25 \%$ bupivacaine on separate occasions. A positive response was $80 \%$ pain relief. ${ }^{42-44,64}$ Controlled, comparative local anesthetic blocks were also performed for suspected sacroiliac joint pain, with $2 \mathrm{~mL}$ of $1 \%$ lidocaine and $0.25 \%$ bupivacaine. ${ }^{42,44}$

Lumbar interlaminar epidural procedures were performed by one physician (LM) in an ambulatory surgery setting, in a sterile operating room, utilizing fluoroscopy. Patients were in the prone position with intravenous access and sedation as indicated. The epidural space entry was confirmed by an injection of non-ionic contrast medium. All procedures were performed either between L5 and S1 or at a higher level based on the patient's pain complaints. Following this, an injection of $6 \mathrm{~mL}$ of lidocaine hydrochloride $0.5 \%$ preservative-free, or $5 \mathrm{~mL}$ of lidocaine mixed with $6 \mathrm{mg}$ of non-particulate betamethasone was given.

\section{Additional interventions}

If a patient required additional lumbar interlaminar epidural injections, these were provided based on the response to the previous injection, with deterioration of pain relief to less than $50 \%$. Patients who were non-responsive and continued with conservative management were followed without further epidural injections with medical management, unless they requested unblinding.

\section{Co-interventions}

There was no specific physical therapy, occupational therapy, bracing, or other interventions offered other than the study intervention. In addition, if patients were improving significantly and the medical necessity for drugs was lacking, medications were stopped or dosages were decreased. For some patients, based on medical necessity, dosages were increased. However, all patients continued previously directed exercise programs, as well as their employment.

\section{Objective}

The study was designed to assess the effectiveness of lumbar interlaminar epidural injections containing local anesthetic with or without steroids in managing chronic axial low back pain of discogenic origin.

\section{Outcomes}

Primary outcome measures included the NRS on a scale of $0-10$, and the ODI on a 0-50 scale. Secondary outcome measures included employment status, and opioid intake in terms of morphine equivalents. The value and validity of the NRS and ODI have been reported. ${ }^{65,66}$ Recently, previously established thresholds were questioned. ${ }^{67,68}$ Thus, significant pain relief or improvement and function were considered to be at least a $50 \%$ reduction in NRS and the ODI, which is similar to the measurements in other trials. . $^{38,46,47,54-62,69-71}$

The opioid intake was converted into morphine equivalents. $^{72}$

Assessment of employment and work status were determined based on employability at the time of enrollment. Thus, they were classified into multiple categories such as employable, housewife with no desire to work outside the home, retired, or over the age of 65. Patients who were unemployed due to pain, employed but on sick leave, or made redundant were considered as employable.

The epidurals were considered to be successful if a patient obtained significant improvement for at least 3 weeks with the first and second procedures. All others were considered to be failures.

\section{Sample size}

The sample size was calculated based on significant pain relief. Considering a 0.05 two-sided significance level, a power of $80 \%$, and an allocation ratio of $1: 1,55$ patients in each group were estimated. ${ }^{73}$ Allowing for a $10 \%$ attrition/ non-compliance rate, 60 patients were required.

\section{Randomization}

Sixty patients were randomly assigned into each group from a total of 120 patients who met inclusion criteria. 


\section{Sequence generation}

Simple randomization was utilized to allocate patients into groups.

\section{Allocation concealment}

Patients were randomized into two groups by one of the three operating room nurses who were also study coordinators. The same person also prepared the drugs.

\section{Blinding (masking)}

The patients and physician were blinded to group assignment and both injectates were clear. In addition, the blinding was ensured by mixing the study patients with other patients receiving routine treatment. All patients chosen for 1-year follow-up were selected by a statistician not participating in provision of the patients' care and the unblinding results were not disclosed to either the treating physician, other participants, or patients. Thus, the nature of blinding was not interrupted.

\section{Statistical methods}

Data analyses were carried out using SPSS software (v 9.01; SPSS Inc, Chicago, IL). For categorical and continuous data comparison, Chi-square (Fisher test where necessary) and $t$-tests were used, respectively. Because the outcome measures of the participants were measured at four points in time, repeated measures analysis of variance were performed with the post hoc analysis.

\section{Intent-to-treat analysis}

Either the last follow-up data or initial data were utilized in the patients who dropped out of the study and no other data were available for the intent-to-treat analysis.

Best case, worst case, and last follow-up score scenarios were used for sensitivity analysis.

\section{Results}

\section{Participant flow}

Figure 1 illustrates the participant flow. The recruitment period lasted from January 2008 through May 2010.

\section{Baseline data}

Table 1 shows the basic demographic characteristics, pain distribution, onset of the pain, numeric rating scale of pain, and ODI for functional status summary scores. There were no statistically significant differences between the two groups in terms of these baseline data (all $P$ values $>0.05$ ), except for weight $(P=0.000)$.

\section{Pain relief and functional assessment}

Table 2 presents the results of repeated measures analysis. Regarding pain scores, there were significant differences within groups by time $(P=0.001)$. In the ODI for functional status, there were significant differences in summary scores within group by time $(P=0.001)$.

A post hoc analysis indicated that all the mean differences between baseline and with the scores at other time points were significant at the 0.05 level.

\section{Pain relief and functional status improvement}

The percentage of patients with significant improvement is presented in Figure 2. In Group I and II, 77\% and 67\% showed significant improvement, respectively. In the successful groups, significant improvement was seen in $84 \%$ in Group I and 71\% in Group II.

\section{Therapeutic procedural characteristics}

Table 3 lists therapeutic procedural characteristics. Lumbar interlaminar procedures were performed in $91 \%$ of cases at $\mathrm{L} 5 / \mathrm{S} 1$ and $9 \%$ of cases at L4/5.

\section{Employment characteristics}

Table 4 lists employment characteristics in both groups. Among the patients eligible for employment, the total employed changed from 12 at baseline to 13 at the end of 12 months in Group I; it changed from 14 to 18 in Group II, a nonsignificant increase of 6\% in Group I and 21\% in Group II.

\section{Opioid intake}

Table 5 presents the results of repeated measures analysis for opioid intake. There were significant differences in opioid intake within group by time $(P<0.001)$. A post hoc analysis indicated that all the mean differences in scores between baseline and other time points were significant at the 0.05 level.

\section{Changes in weight}

Table 6 shows changes in weight, with no significant differences in changes among the groups.

\section{Adverse events}

Of the 454 lumbar epidural procedures performed, there were two subarachnoid punctures that did not result in headache. One patient experienced weight gain due to a high dose of steroid from an unrelated medical problem. 


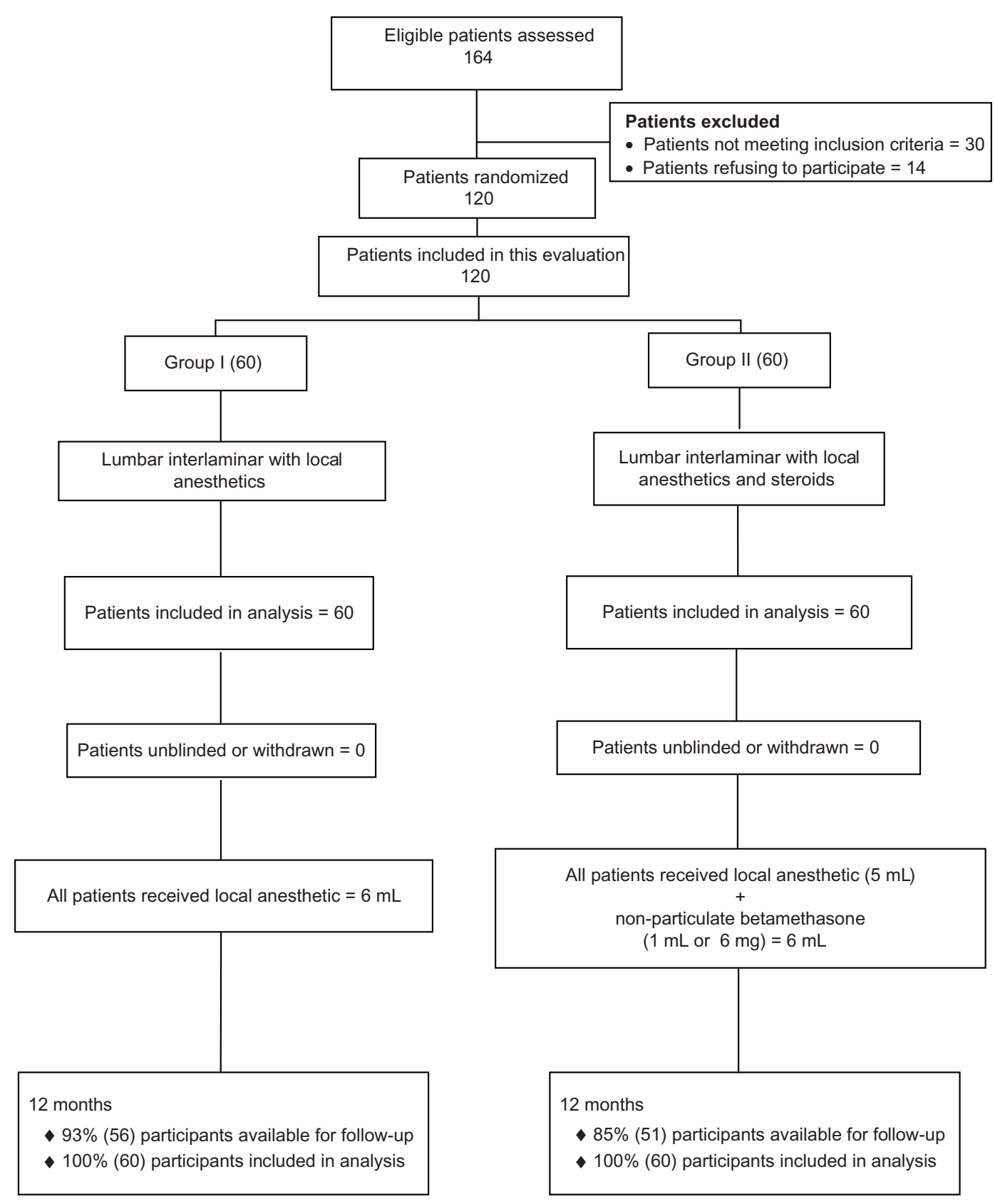

Figure I Schematic presentation of participant flow at I-year follow-up of 60 patients.

\section{Discussion}

This randomized, active control trial shows that carefully selected patients with axial or discogenic chronic low back pain can receive significant pain relief and functional status improvement with lumbar interlaminar epidural injections. Their pain was not caused by disc herniation, facet joints, or the sacroiliac joints. Significant pain relief and functional status improvement of $\geq 50 \%$ were seen in $77 \%$ of Group I and
$67 \%$ of Group II. A better picture emerges when each group was divided into failed and successful outcomes. Significant pain relief and functional status improvement was seen in $84 \%$ of the successful outcomes in Group I; 71\% in the successful outcomes in Group II. The average procedures per year and average weeks of total relief for the successful outcome patients were: Group I, 3.9 procedures and $40.0 \pm 15.6$ weeks; Group II, 4.0 procedures and $39.6 \pm 12.4$ weeks. 
Table I Baseline demographic and clinical data

\begin{tabular}{|c|c|c|c|}
\hline & $\begin{array}{l}\text { Group I } \\
(60)\end{array}$ & $\begin{array}{l}\text { Group II } \\
(60)\end{array}$ & $P$-value \\
\hline \multicolumn{4}{|l|}{ Sex } \\
\hline Male & $23 \%(14)$ & $40 \%(24)$ & 0.077 \\
\hline Female & $77 \%(46)$ & $60 \%(36)$ & \\
\hline \multicolumn{4}{|l|}{ Age } \\
\hline Mean \pm SD & $41.2 \pm 11.9$ & $42.7 \pm 11.4$ & 0.477 \\
\hline \multicolumn{4}{|l|}{ Weight } \\
\hline Mean \pm SD & $211.2 \pm 60.9$ & $168.6 \pm 40.6$ & 0.000 \\
\hline \multicolumn{4}{|l|}{ Height } \\
\hline Mean $\pm S D$ & $65.8 \pm 3.7$ & $66.4 \pm 4.1$ & 0.430 \\
\hline \multicolumn{4}{|c|}{ Duration of pain (months) } \\
\hline Mean \pm SD & $104.2 \pm 106.5$ & $129.0 \pm 90.9$ & 0.173 \\
\hline \multicolumn{4}{|l|}{ Onset of pain } \\
\hline Gradual & $67 \%(40)$ & $70 \%(42)$ & 0.845 \\
\hline Injury & $33 \%(20)$ & $30 \%(18)$ & \\
\hline \multicolumn{4}{|l|}{ Pain distribution } \\
\hline Unilateral & $20 \%(I 2)$ & $25 \%(15)$ & 0.662 \\
\hline Bilateral & $80 \%(48)$ & $75 \%(45)$ & \\
\hline \multicolumn{4}{|l|}{ Back pain distribution } \\
\hline Back pain only & $15 \%(9)$ & $20 \%(12)$ & 0.849 \\
\hline $\begin{array}{l}\text { Back pain worse than } \\
\text { leg pain }\end{array}$ & $65 \%(39)$ & $60 \%(36)$ & \\
\hline $\begin{array}{l}\text { Leg pain worse than } \\
\text { back pain }\end{array}$ & $5 \%(3)$ & $3 \%(2)$ & \\
\hline Both equal & $15 \%(9)$ & $17 \%(10)$ & \\
\hline \multicolumn{4}{|l|}{ Numeric rating score } \\
\hline Mean \pm SD & $8.0 \pm 1.0$ & $7.7 \pm 0.9$ & 0.082 \\
\hline \multicolumn{4}{|l|}{ Oswestry disability index } \\
\hline Mean \pm SD & $30.7 \pm 4.5$ & $29.2 \pm 5.2$ & 0.096 \\
\hline
\end{tabular}

The results of this evaluation essentially illustrate that if patients are selected appropriately, lumbar epidural injections provide significant improvement. These results are in line with other studies separating the patients into failed and successful groups. ${ }^{38,46,47,54,55,58-62}$ The results illustrate that both pain relief and improvement in functional status are clinically and statistically significant. Strict criteria were incorporated into the study and only participating patients judged not to have facet joint or sacroiliac joint pain were included, thus avoiding the criticism that including those with facet joint or sacroiliac joint pain in a study contributes to negative results. As confirmed in this report, epidural injections do not provide long-term relief. But, properly selected patients and appropriate procedures under fluoroscopy can provide long-term relief with judicious use.

Despite multiple publications, there is still significant debate regarding the medical necessity and indications for lumbar epidural injections, either by interlaminar approach, caudal approach, or transforaminal approach. Multiple systematic reviews, guidelines, and other reviews have identified weak indications for epidural injections, namely radicular pain from herniated lumbar intervertebral discs. However, there is a lack of evidence or recommended indications for other conditions. The preliminary report of the current manuscript showed positive results with interlaminar epidural injections. ${ }^{39}$ Similarly, the previous results with caudal epidurals in appropriately selected patients were positive. ${ }^{38}$

The results of this evaluation are similar to caudal epidural injections for axial or discogenic pain. ${ }^{38}$ However, overall relief was superior in the present study, compared to the caudal study. ${ }^{38}$ Steroids did not have any superiority over local anesthetic alone in either study.

There is a paucity of literature evaluating epidural injections for axial or discogenic pain. The role of caudal epidural injections for axial or discogenic pain, after ruling out facet joint pain or diagnosing it with provocation discography, was evaluated in three studies. ${ }^{38,74,75}$ Only one study ${ }^{51}$ looked at lumbar interlaminar epidural injections other than the pre-

Table 2 Comparison of numeric rating scale for pain and Oswestry disability index score summaries at four time points

\begin{tabular}{|c|c|c|c|c|}
\hline \multirow[t]{3}{*}{ Time points } & \multicolumn{2}{|c|}{ Numeric pain rating scale } & \multicolumn{2}{|c|}{ Oswestry disability index } \\
\hline & $\begin{array}{l}\text { Group I } \\
(60)\end{array}$ & $\begin{array}{l}\text { Group II } \\
(60)\end{array}$ & $\begin{array}{l}\text { Group I } \\
(60)\end{array}$ & $\begin{array}{l}\text { Group II } \\
(60)\end{array}$ \\
\hline & Mean \pm SD & Mean \pm SD & Mean \pm SD & Mean \pm SD \\
\hline Baseline & $8.0 \pm 1.0$ & $7.7 \pm 0.9$ & $30.7 \pm 4.5$ & $29.2 \pm 5.2$ \\
\hline 3 months & $\begin{array}{l}3.6 * \pm 0.9 \\
(88 \%)\end{array}$ & $\begin{array}{l}3.5 * \pm 1.2 \\
(83 \%)\end{array}$ & $\begin{array}{l}14.9 * \pm 4.3 \\
(83 \%)\end{array}$ & $\begin{array}{l}|4.6 * \pm 5 .| \\
(78 \%)\end{array}$ \\
\hline 6 months & $\begin{array}{l}3.9 * \pm 1.1 \\
(77 \%)\end{array}$ & $\begin{array}{l}3.6 * \pm 1.2 \\
(82 \%)\end{array}$ & $\begin{array}{l}15.4 * \pm 4.8 \\
(73 \%)\end{array}$ & $\begin{array}{l}14.4^{*} \pm 5.2 \\
(77 \%)\end{array}$ \\
\hline 12 months & $\begin{array}{l}3.7^{*} \pm 1.2 \\
(78 \%)\end{array}$ & $\begin{array}{l}3.7^{*} \pm 1.3 \\
(72 \%)\end{array}$ & $\begin{array}{l}14.9 * \pm 5.0 \\
(77 \%)\end{array}$ & $\begin{array}{l}15.0 * \pm 6.4 \\
(70 \%)\end{array}$ \\
\hline Group difference & \multicolumn{2}{|c|}{0.208} & \multicolumn{2}{|c|}{0.395} \\
\hline Time difference & \multicolumn{2}{|c|}{0.001} & \multicolumn{2}{|c|}{0.001} \\
\hline Group by time interaction & \multicolumn{2}{|c|}{0.448} & \multicolumn{2}{|c|}{0.210} \\
\hline
\end{tabular}

Notes: Lower the value, the better the condition; *Significant difference with baseline values within the group $(P<0.05)$; ( ) illustrates proportion with significant pain relief $(\geq 50 \%)$ from baseline. 


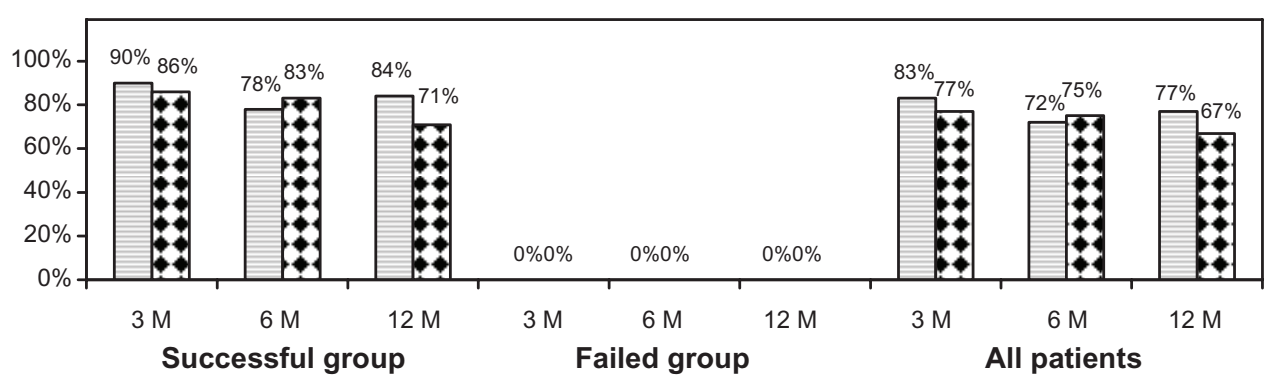

Figure 2 Percentage of patients with a significant reduction in Numeric Rating Score and Oswestry disability index ( $\geq 50 \%$ reduction from baseline).

liminary version of this study. ${ }^{39}$ Butterman $^{51}$ evaluated the role of interlaminar epidural steroids showing improvement only at the 3-month follow-up. All of the studies reported modest results.

The mechanism of action of steroids and local anesthetics continues to be debated. Multiple hypothesis have been emerging. ${ }^{76-84}$ The evidence shows that steroids, as well as local anesthetics, have significant effects on the modulation of noxious stimulation by various mechanisms. Long-term effects are provided by both local anesthetics and steroids or when in combination, in experimental as well as clinical studies. $^{38,46,47,54-56,58-61,76-84}$

Comparative effectiveness research and evidence-based medicine have been considered as pivotal to health care policy not only in the US, but across the world. ${ }^{10,11,85-89}$ In general, practical studies conducted in a generally applicable environment are considered more valuable than pragmatic or practical clinical trials with an active control group instead of a placebo group. Practical studies measure effectiveness, which is considered more appropriate than explanatory trials which measure efficacy. ${ }^{90-93}$ Thus, this study meets the criteria for a practical clinical trial, specifically in contemporary interventional pain management practices; it meets the appropriate selection criteria and repeats the procedures based upon the return of pain, rather than a predetermined schedule. The procedures were performed under fluoroscopy, only after conservative management had failed. The study also confirms the long-held belief that if the first two procedures do not provide at least a minimum of 3 weeks of relief, the procedures may not provide relief on a long-term basis. This was observed in the failed patients, suggesting that it may be futile to continue to repeat these procedures in these patients, unless there are compelling reasons to do so.

Table 3 Therapeutic procedural characteristics with procedural frequency, average relief per procedure, and average total relief in weeks over a period of I year

\begin{tabular}{|c|c|c|c|c|c|c|}
\hline \multirow[t]{2}{*}{ Average relief } & \multicolumn{2}{|c|}{ Successful patients } & \multicolumn{2}{|c|}{ Failed patients } & \multicolumn{2}{|l|}{ Combined } \\
\hline & $\begin{array}{l}\text { Group I } \\
\text { (55) }\end{array}$ & $\begin{array}{l}\text { Group II } \\
\text { (54) }\end{array}$ & $\begin{array}{l}\text { Group I } \\
\text { (5) }\end{array}$ & $\begin{array}{l}\text { Group II } \\
\text { (6) }\end{array}$ & $\begin{array}{l}\text { Group I } \\
(60)\end{array}$ & $\begin{array}{l}\text { Group II } \\
(60)\end{array}$ \\
\hline Ist procedure relief & $\begin{array}{l}6.1 \pm 3.8 \\
(55)\end{array}$ & $\begin{array}{l}6.5 \pm 4.3 \\
(54)\end{array}$ & $\begin{array}{l}0.9 \pm 1.0 \\
(5)\end{array}$ & $\begin{array}{l}0.5 \pm 0.8 \\
(6)\end{array}$ & $\begin{array}{l}5.7 \pm 4.0 \\
(60)\end{array}$ & $\begin{array}{l}5.9 \pm 4.5 \\
(60)\end{array}$ \\
\hline 2nd procedure relief & $\begin{array}{l}10.2 \pm 6.8 \\
(55)\end{array}$ & $\begin{array}{l}10.0 \pm 6.7 \\
(54)\end{array}$ & $\begin{array}{l}1.0 \pm 1.4 \\
(2)\end{array}$ & $\begin{array}{l}0.8 \pm 1.1 \\
(3)\end{array}$ & $\begin{array}{l}9.9 \pm 6.9 \\
(57)\end{array}$ & $\begin{array}{l}9.5 \pm 6.8 \\
(57)\end{array}$ \\
\hline 3rd procedure relief & $\begin{array}{l}11.9 \pm 4.1 \\
(51)\end{array}$ & $\begin{array}{l}11.0 \pm 3.5 \\
(50)\end{array}$ & $\begin{array}{l}2.0 \\
(I)\end{array}$ & $\begin{array}{l}5.0 \pm 5.7 \\
(2)\end{array}$ & $\begin{array}{l}11.7 \pm 4.3 \\
(52)\end{array}$ & $\begin{array}{l}10.8 \pm 3.7 \\
(52)\end{array}$ \\
\hline 4th procedure relief & $\begin{array}{l}12.2 \pm 4.5 \\
(38)\end{array}$ & $\begin{array}{l}12.3 \pm 2.3 \\
(4 I)\end{array}$ & - & $\begin{array}{l}2.0 \pm 1.4 \\
(2)\end{array}$ & $\begin{array}{l}12.2 \pm 4.5 \\
(38)\end{array}$ & $\begin{array}{l}11.8 \pm 3.1 \\
(43)\end{array}$ \\
\hline 5th procedure relief & $\begin{array}{l}12.6 \pm 1.1 \\
(16)\end{array}$ & $\begin{array}{l}13.3 \pm 2.7 \\
(18)\end{array}$ & - & - & $\begin{array}{l}12.6 \pm 1.1 \\
(16)\end{array}$ & $\begin{array}{l}13.3 \pm 2.7 \\
(18)\end{array}$ \\
\hline Number of procedures per year & $3.9 \pm 0.9$ & $4.0 \pm 0.9$ & $1.6 \pm 0.9$ & $2.2 \pm 1.5$ & $3.7 \pm \mathrm{I} . \mathrm{I}$ & $3.8 \pm 1.1$ \\
\hline For initial 2 procedures in weeks & $8.6 \pm 10.0$ & $8.2 \pm 5.9$ & $0.9 \pm 1.0$ & $0.6 \pm 0.8$ & $8.2 \pm 9.9$ & $7.6 \pm 6.0$ \\
\hline After initial 2 procedures & $12.1 \pm 3.9$ & $11.9 \pm 3.1$ & 2.0 & $3.5 \pm 3.8$ & $12.0 \pm 4.0$ & $11.6 \pm 3.4$ \\
\hline All procedures & $\begin{array}{l}10.1 \pm 5.4 \\
(215)\end{array}$ & $\begin{array}{l}10.1 \pm 5.0 \\
(218)\end{array}$ & $\begin{array}{l}1.1 \pm 1.0 \\
(8)\end{array}$ & $\begin{array}{l}1.5 \pm 2.5 \\
(13)\end{array}$ & $\begin{array}{l}9.8 \pm 5.6 \\
(223)\end{array}$ & $\begin{array}{l}9.7 \pm 5.3 \\
(23 I)\end{array}$ \\
\hline Total relief per year (weeks) & $40.0 \pm 15.6$ & $39.6 \pm 12.4$ & $1.6 \pm 1.7$ & $3.2 \pm 5.4$ & $36.8 \pm 18.4$ & $36.0 \pm 16.2$ \\
\hline
\end{tabular}

Note: Successful groups had at least 3 weeks of relief with first two procedures. 
Table 4 Employment characteristics

\begin{tabular}{|c|c|c|c|c|}
\hline \multirow{2}{*}{$\begin{array}{l}\text { Employment } \\
\text { status }\end{array}$} & \multicolumn{2}{|l|}{ Group I } & \multicolumn{2}{|l|}{ Group II } \\
\hline & Baseline & 12 months & Baseline & 12 months \\
\hline $\begin{array}{l}\text { Employed } \\
\text { part-time }\end{array}$ & 7 & 5 & 3 & 5 \\
\hline $\begin{array}{l}\text { Employed } \\
\text { full-time }\end{array}$ & 5 & 8 & 11 & 13 \\
\hline $\begin{array}{l}\text { Unemployed } \\
\text { (due to pain) }\end{array}$ & 2 & I & 2 & 0 \\
\hline Not working & 3 & 4 & 3 & 1 \\
\hline $\begin{array}{l}\text { Eligible for } \\
\text { employment }\end{array}$ & 17 & 17 & 19 & 19 \\
\hline Total employed & 12 & 13 & 14 & 18 \\
\hline Housewife & 3 & 3 & 7 & 7 \\
\hline Disabled & 39 & 38 & 32 & 32 \\
\hline Retired/over 65 & 1 & 1 & 2 & 2 \\
\hline $\begin{array}{l}\text { Total number } \\
\text { of patients }\end{array}$ & 60 & 60 & 60 & 60 \\
\hline
\end{tabular}

The present study may be criticized for not focusing on a placebo group. However, most studies have utilized inappropriate methodology with placebo groups with reference to interventional techniques..$^{88,89,94-99}$ The only appropriately designed placebo trial by Ghahreman et $\mathrm{al}^{99}$ showed a lack of significant effect when sodium chloride solution was injected into an inactive structure. Consequently, when sodium chloride solution or other agents such as local anesthetics, which are considered as placebo by some do not yield the same results, this leads to inaccurate methodology and conclusions. ${ }^{100-103}$

Some of the other weaknesses include differences in baseline demographic characteristics with respect to weight and sex; however, these differences were not considered to have caused any significant effect on the final results.

The implications of this trial are enormous in the health care arena. Studies with proper methodology in practical settings are not only crucial, but mandatory. Proper application of interventions will improve not only patients' pain and function and reduce drug use, it may also return them

Table 5 Comparison of opioid intake (morphine equivalents in $\mathrm{mg}$ ) summaries at four time points

\begin{tabular}{lcc}
\hline Time & $\begin{array}{l}\text { Group I } \\
(\mathbf{6 0 )}\end{array}$ & $\begin{array}{l}\text { Group II } \\
\mathbf{( 6 0 )}\end{array}$ \\
\cline { 2 - 3 } & Mean \pm SD & Mean \pm SD \\
\hline Baseline & $57.2 \pm 61.4$ & $53.4 \pm 53.8$ \\
3 months & $35.5^{\#} \pm 24.2$ & $40.3^{\#} \pm 35.7$ \\
6 months & $36.1^{\#} \pm 27.0$ & $41.8^{\#} \pm 37.3$ \\
I2 months & $36.3^{\#} \pm 27.0$ & $41.8^{\#} \pm 37.3$ \\
Group difference & & 0.366 \\
Time difference & & 0.001 \\
Group by time interaction & & 0.629 \\
\hline
\end{tabular}

Note: "Significant difference from their baseline values $(P<0.05)$.
Table 6 Characteristics of weight monitoring

\begin{tabular}{|c|c|c|c|}
\hline \multirow[t]{2}{*}{ Weight (Ibs) } & \multirow{2}{*}{$\frac{\text { Group I (60) }}{\text { Mean } \pm \text { SD }}$} & \multirow{2}{*}{$\frac{\text { Group II (60) }}{\text { Mean } \pm \text { SD }}$} & \multirow[t]{2}{*}{$P$-value } \\
\hline & & & \\
\hline Weight at beginning & $211.2 \pm 60.9$ & $168.6 \pm 40.6$ & 0.000 \\
\hline Weight at I year & $211.4 \pm 64.0$ & $166.1 \pm 40.5$ & 0.000 \\
\hline Change & $0.2 \pm 13.3$ & $-2.5 \pm 10.8$ & 0.227 \\
\hline Lost weight & $37 \%(22)$ & $57 \%(34)$ & \\
\hline No change & $23 \%(14)$ & $13 \%(8)$ & 0.078 \\
\hline Gained weight & $40 \%(24)$ & $30 \%(18)$ & \\
\hline
\end{tabular}

to the workforce; however, by the same token, inappropriate provision of any type of intervention, specifically interventions with substantial expenses, will not provide any benefit. Instead, it can harm the patient, thus depleting resources and reducing access. Similarly, inappropriately performed evaluations in the name of methodology, leading to inaccurate conclusions, may reduce health care expenditures, and will also increase patient suffering and reduce function by impeding access to much needed medical care.

\section{Conclusion}

This study illustrates that overall significant improvement was seen in $77 \%$ of the patients in Group I and $67 \%$ of the patients in Group II. In the successful outcome groups, in those who received at least 3 weeks of relief with the first two procedures, the improvement was $84 \%$ in Group I and $71 \%$ in Group II. Pain relief and functional status improvement was achieved with an average procedures per year in the successful outcome groups of 3.9 in Group I and 4.0 in Group II, and an average total relief per year of $40.0 \pm 15.6$ weeks in Group I and 39.6 \pm 12.4 in Group II.

\section{Acknowledgments/ethics approval}

Dr Manchikanti and Dr Benyamin designed the study; Mr Pampati performed the statistical analysis, and Ms Cash and Ms McManus were two of the three coordinators. The study was approved by the IRB and was registered in the US Clinical Trial Registry. All ethical guidelines were followed.

\section{Disclosure}

The authors report no conflicts of interest in this work.

\section{References}

1. Manchikanti L, Pampati V, Boswell MV, Smith HS, Hirsch JA. Analysis of the growth of epidural injections and costs in the Medicare population: a comparative evaluation of 1997, 2002, and 2006 data. Pain Physician. 2010;13(3):199-212.

2. Manchikanti L, Boswell MV, Singh V, et al; ASIPP-IPM. Comprehensive evidence-based guidelines for interventional techniques in the management of chronic spinal pain. Pain Physician. 2009;12(4):699-802. 
3. Staal JB, de Bie RA, de Vet HC, Hildebrandt J, Nelemans P. Injection therapy for subacute and chronic low back pain: an updated Cochrane review. Spine (Phila Pa 1976). 2009;34(1):49-59.

4. Chou R, Huffman L. Guideline for the Evaluation and Management of Low Back Pain: Evidence Review. Glenview, IL: American Pain Society; 2009. Available at: http://www.ampainsoc.org/pub/pdf/ LBPEvidRev.pdf. Accessed on May 14, 2012.

5. Manchikanti L, Singh V, Caraway DL, Benyamin RM, Hirsch JA. Medicare physician payment systems: impact of 2011 schedule on interventional pain management. Pain Physician. 2011;14(1): E5-E33.

6. Bogduk N, Christophidis N, Cherry D. Epidural use of steroids in the management of back pain. Report of working party on epidural use of steroids in the management of back pain. National Health and Medical Research Council. Commonwealth of Australia: Canberra; 1994: 1-76.

7. Friedly J, Chan L, Deyo R. Increases in lumbosacral injections in the Medicare population: 1994 to 2001. Spine (Phila Pa 1976). 2007;32(16):1754-1760.

8. Manchikanti L, Pampati V, Singh V, Boswell MV, Smith HS, Hirsch JA. Explosive growth of facet joint interventions in the Medicare population in the United States: a comparative evaluation of 1997, 2002, and 2006 data. BMC Health Serv Res. 2010;10:84.

9. Manchikanti L, Singh V, Hirsch JA. Saga of payment systems of ambulatory surgery centers for interventional techniques: an update. Pain Physician. 2012;15(2):109-130.

10. Manchikanti L, Datta S, Derby R, Wolfer LR, Benyamin RM, Hirsch JA. A critical review of the American Pain Society clinical practice guidelines for interventional techniques: part 1. Diagnostic interventions. Pain Physician. 2010;13:(3)E141-E174.

11. Manchikanti L, Datta S, Gupta S, et al. A critical review of the American Pain Society clinical practice guidelines for interventional techniques: part 2. Therapeutic interventions. Pain Physician. 2010;13(4): E215-E264.

12. Abbott ZI, Nair KV, Allen RR, Akuthota VR. Utilization characteristics of spinal interventions. Spine J. 2012;12(1):35-43.

13. Wheeler AH, Murrey DB. Chronic lumbar spine and radicular pain: pathophysiology and treatment. Curr Pain Headache Rep. 2002;6(2):97-105.

14. Hadjipavlou AG, Tzermiadianos MN, Bogduk N, Zindrick MR. The pathophysiology of disc degeneration: a critical review. $J$ Bone Joint Surg Br. 2008;90(10):1261-1270.

15. McCarron RF, Wimpee MW, Hudkins PG, Laros GS. The inflammatory effects of nucleus pulposus: a possible element in the pathogenesis of low back pain. Spine (Phila Pa 1976). 1987;12(8):760-764.

16. Olmarker K, Nordborg C, Larsson K, Rydevik B. Ultrastructural changes in spinal nerve roots induced by autologous nucleus pulposus. Spine (Phila Pa 1976). 1996;21(4):411-414.

17. Mixter WJ, Barr JS. Rupture of the intervertebral disc with involvement of the spinal canal. N Eng J Med. 1934; 211:210-215.

18. Mixter WJ, Ayers JB. Herniation or rupture of the intervertebral disc into the spinal canal. N Engl J Med. 1935;213:385-395.

19. Manchikanti L, Boswell MV, Singh V, et al; ASIPP. Comprehensive review of neurophysiologic basis and diagnostic interventions in managing chronic spinal pain. Pain Physician. 2009;12(4):E71-E120.

20. Hancock MJ, Maher CG, Latimer J, et al. Systematic review of tests to identify the disc, SIJ or facet joint as the source of low back pain. Eur Spine J. 2007; 16(10):1539-1550.

21. Peng B, Wu W, Hou S, et al. The pathogenesis of discogenic low back pain. J Bone Joint Surg. 2005;87(1):62-67.

22. Miyagi M, Ishikawa T, Orita S, et al. Disk injury in rats produces persistent increases in pain-related neuropeptides in dorsal root ganglia and spinal cord glia but only transient increases in inflammatory mediators: pathomechanism of chronic diskogenic low back pain. Spine (Phila Pa 1976). 2011;36(26):2260-2266.

23. Coppes MH, Marani E, Thomeer RT, Groen GJ. Innervation of "painful" lumbar discs. Spine (Phila Pa 1976). 1997;22(20):2342-2349.
24. Freemont AJ, Peacock TE, Goupille P, Hoyland JA, O’Brien J, Jayson MI. Nerve ingrowth into diseased intervertebral disc in chronic back pain. Lancet. 1997;350(9072):178-181.

25. Edgar MA. The nerve supply of the lumbar intervertebral disc. $J$ Bone Joint Surg. 2007;89(9):1135-1139.

26. Ozawa T, Ohtori S, Inoue G, Aoki Y, Moriya H, Takahashi K. The degenerated lumbar intervertebral disc is innervated primarily by peptide-containing sensory nerve fibers in humans. Spine (Phila Pa 1976). 2006;31(21):2418-2422.

27. Aoki Y, Ohtori S, Ino H, et al. Disc inflammation potentially promotes axonal regeneration of dorsal root ganglion neurons innervating lumbar intervertebral disc in rats. Spine (Phila Pa 1976). 2004;29(23):2621-2626.

28. Hayashi Y, Ohtori S, Yamashita M, et al. Direct single injection of p38 mitogen-activated protein kinase inhibitor does not affect calcitonin gene-related peptide expression in dorsal root ganglion neurons innervating punctured discs in rats. Spine (Phila Pa 1976). 2009;24(26):2295-2299 .

29. Helm S, Hayek SM, Benyamin RM, Manchikanti L. Systematic review of the effectiveness of thermal annular procedures in treating discogenic low back pain. Pain Physician. 2009;12(1):207-232.

30. Blondel B, Tropiano P, Guadart J, Huang RC, Marnay T. Clinical results of lumbar total disc arthroplasty in accordance with Modic signs, with a 2-year-minimum follow-up. Spine (Phila Pa 1976). 2011;36(26):2309-2315.

31. Oh WS, Shim JC. A randomized controlled trial of radiofrequency denervation of the ramus communicans nerve for chronic discogenic low back pain. Clin J Pain. 2004;20(1):55-60.

32. Tsou PM, Yeung CA, Yeung AT. Posterolateral transforaminal selective endoscopic discectomy and thermal annuloplasty for chronic lumbar discogenic pain: a minimal access visualized intradiscal surgical procedure. Spine J. 2004; 4(5):564-573.

33. Peng B, Pang X, Zhao C, Song X. A randomized placebo-controlled trial of intradiscal methylene blue injection for the treatment of chronic discogenic low back pain. Pain. 2010;149(1):124-129.

34. Ohtori S, Kinoshita T, Yamashita M, et al. Results of surgery for discogenic low back pain: A randomized study using discography versus discoblock for diagnosis. Spine (Phila Pa 1976). 2009;34(13):1345-1348.

35. Ohtori S, Koshi T, Yamashita M, et al. Surgical versus nonsurgical treatment of selected patients with discogenic low back pain: a smallsized randomized trial. Spine (Phila Pa 1976). 2011;36(5):347-354.

36. Madan S, Gundanna M, Harley JM, Boeree NR, Sampson M. Does provocative discography screening of discogenic back pain improve surgical outcome? J Spinal Disord Tech. 2002;15(3):245-251.

37. Maghout-Juratli S, Franklin GM, Mirza SK, Wickizer TM, FultonKohoe D. Lumbar fusion outcomes in Washington state workers' compensation. Spine (Phila Pa 1976). 2006;31(23):2715-2723.

38. Manchikanti L, Cash KA, McManus CD, Pampati V, Smith HS. One year results of a randomized, double-blind, active controlled trial of fluoroscopic caudal epidural injections with or without steroids in managing chronic discogenic low back pain without disc herniation or radiculitis. Pain Physician. 2011;14(1):25-36.

39. Manchikanti L, Cash KA, McManus CD, Pampati V, Benyamin RM. Preliminary results of a randomized, double-blind, controlled trial of fluoroscopic lumbar interlaminar epidural injections in managing chronic lumbar discogenic pain without disc herniation or radiculitis. Pain Physician. 2010;13(4):E279-E292.

40. Vallejo R, Manuel Zevallos L, Lowe J, Benyamin R. Is spinal cord stimulation an effective treatment option for discogenic pain? Pain Pract. 2012;12(3):194-201.

41. Schwarzer AC, Aprill CN, Derby R, Fortin J, Kine G, Bogduk N. The relative contributions of the disc and zygapophyseal joint in chronic low back pain. Spine (Phila Pa 1976). 1994;19(7):801-806.

42. Manchikanti L, Singh V, Pampati V, et al. Evaluation of the relative contributions of various structures in chronic low back pain. Pain Physician. 2001;4(4):308-316. 
43. Datta S, Lee M, Falco FJE, Bryce DA, Hayek SM. Systematic assessment of diagnostic accuracy and therapeutic utility of lumbar facet joint interventions. Pain Physician. 2009;12(2):437-460.

44. Rupert MP, Lee M, Manchikanti L, Datta S, Cohen SP. Evaluation of sacroiliac joint interventions: a systematic appraisal of the literature. Pain Physician. 2009;12(2):399-418.

45. Parr AT, Diwan S, Abdi S. Lumbar interlaminar epidural injections in managing chronic low back and lower extremity pain: a systematic review. Pain Physician. 2009;12(1):163-188.

46. Manchikanti L, Singh V, Falco FJE, Cash KA, Pampati V. Evaluation of the effectiveness of lumbar interlaminar epidural injections in managing chronic pain of lumbar disc herniation or radiculitis: a randomized, double-blind, controlled trial. Pain Physician. 2010;13(4):343-355.

47. Manchikanti L, Cash KA, McManus CD, Damron KS, Pampati V, Falco FJE. Lumbar interlaminar epidural injections in central spinal stenosis: preliminary results of a randomized, double-blind, active control trial. Pain Physician. 2012;15(1):51-63.

48. Ackerman WE 3rd, Ahmad M. The efficacy of lumbar epidural steroid injections in patients with lumbar disc herniations. Anesth Analg. 2007;104(5):1217-1222.

49. Candido KD, Raghavendra MS, Chinthagada M, Badiee S, Trepashko DW. A prospective evaluation of iodinated contrast flow patterns with fluoroscopically guided lumbar epidural steroid injections: the lateral parasagittal interlaminar epidural approach versus the transforaminal epidural approach. Anesth Analg. 2008;106(2):638-644.

50. Gharibo C, Varlotta G, Rhame E, Liu ECJ, Bendo J, Perloff M. Interlaminar versus transforaminal epidural steroids for the treatment of sub-acute lumbar radicular pain: a randomized, blinded, prospective outcome study. Pain Physician. 2011;14(6):499-511.

51. Butterman GR. The effect of spinal steroid injections for degenerative disc disease. Spine J. 2004;4(5):495-505.

52. Amr YM. Effect of addition of epidural ketamine to steroid in lumbar radiculitis: one-year follow-up. Pain Physician. 2011;14(5):475-481.

53. Rados I, Sakic K, Fingler M, Kapural L. Efficacy of interlaminar vs transforaminal epidural steroid injection for the treatment of chronic unilateral radicular pain: prospective, randomized study. Pain Med. 2011;12(9):1316-1321.

54. Manchikanti L, Singh V, Cash KA, Pampati V, Damron KS, Boswell MV. A randomized, controlled, double-blind trial of fluoroscopic caudal epidural injections in the treatment of lumbar disc herniation and radiculitis. Spine (Phila Pa 1976). 2011;36(23):1897-1905.

55. Manchikanti L, Singh V, Cash KA, Pampati V, Datta S. Management of pain of post lumbar surgery syndrome: one-year results of a randomized, double double-blind, active controlled trial of fluoroscopic caudal epidural injections. Pain Physician. 2010;13(6):509-521.

56. Manchikanti L, Cash RA, McManus CD, Pampati V, Fellows B. Fluoroscopic caudal epidural injections with or without steroids in managing pain of lumbar spinal stenosis: One year results of randomized, double-blind, active-controlled trial. J Spinal Disord. 2012;25: 226-234.

57. Dashfield AK, Taylor MB, Cleaver JS, Farrow D. Comparison of caudal steroid epidural with targeted steroid placement during spinal endoscopy for chronic sciatica: a prospective, randomized, double-blind trial. $\mathrm{Br} J$ Anaesth. 2005;94(4):514-559.

58. Manchikanti L, Cash KA, Pampati V, Wargo BW, Malla Y. Cervical epidural injections in chronic discogenic neck pain without disc herniation or radiculitis: preliminary results of a randomized, double-blind, controlled trial. Pain Physician. 2010;13(4):E265-E278.

59. Manchikanti L, Cash KA, Pampati V, Wargo BW, Malla Y. The effectiveness of fluoroscopic cervical interlaminar epidural injections in managing chronic cervical disc herniation and radiculitis: preliminary results of a randomized, double-blind, controlled trial. Pain Physician. 2010;13(3):223-236.

60. Manchikanti L, Malla Y, Cash KA, McManus CD, Pampati V. Fluoroscopic epidural injections in cervical spinal stenosis: preliminary results of a randomized, double-blind, active control trial. Pain Physician. 2012;15(1):E59-E70.
61. Manchikanti L, Malla Y, Cash KA, McManus CD, Pampati V. Fluoroscopic cervical interlaminar epidural injections in managing chronic pain of cervical post-surgery syndrome: preliminary results of a randomized, double-blind active control trial. Pain Physician. 2012;15(1):13-26.

62. Manchikanti L, Cash KA, McManus CD, Pampati V, Benyamin RM. A preliminary report of a randomized double-blind, active controlled trial of fluoroscopic thoracic interlaminar epidural injections in managing chronic thoracic pain. Pain Physician. 2010;13(6):E357-E369.

63. Altman DG, Schulz KF, Moher D, et al; CONSORT GROUP. The revised CONSORT statement for reporting randomized trials: explanation and elaboration. Ann Intern Med. 2001;134(8): 663-694.

64. Manchukonda R, Manchikanti KN, Cash KA, Pampati V, Manchikanti L. Facet joint pain in chronic spinal pain: an evaluation of prevalence and false-positive rate of diagnostic blocks. J Spinal Disord Tech. 2007;20(7):539-545

65. Manchikanti L, Hirsch JA, Smith HS. Evidence-based medicine, systematic reviews, and guidelines in interventional pain management: part 2: Randomized controlled trials. Pain Physician. 2008;11(6): 717-773.

66. Fairbank JCT, Pynsent PB. The Oswestry Disability Index. Spine (Phila Pa 1976). 2000;25(22):2940-2953.

67. Carragee EJ. The rise and fall of the "minimum clinically important difference". Spine J. 2010;10(4):283-284.

68. Carragee EJ, Chen I. Minimum acceptable outcomes after lumbar spinal fusion. Spine J. 2010;10(4):313-320.

69. Manchikanti L, Singh V, Falco FJE, Cash KA, Pampati V. Evaluation of lumbar facet joint nerve blocks in managing chronic low back pain: a randomized, double-blind, controlled trial with a 2-year follow-up. Int J Med Sci. 2010;7(3):124-135.

70. Manchikanti L, Singh V, Falco FJE, Cash KA, Pampati V, Fellows B. Comparative effectiveness of a one-year follow-up of thoracic medial branch blocks in management of chronic thoracic pain: a randomized, double-blind active controlled trial. Pain Physician. 2010;13(6):535-548.

71. Manchikanti L, Singh V, Falco FJ, Cash KA, Fellows B. Comparative outcomes of a 2-year follow-up of cervical medial branch blocks in management of chronic neck pain: a randomized, double-blind controlled trial. Pain Physician. 2010;13(5):437-450.

72. Pereira J, Lawlor P, Vigano A, Dorgan M, Bruera E. Equianalgesic dose ratios for opioids. A critical review and proposals for long-term dosing. $J$ Pain Symptom Manage. 2001;22(2):672-687. Narcotic analgesic converter, GlobalRPh Inc, http://www.globalrph.com/narcotic.cgi.

73. Browner WS, Newman TB, Cummings SR, Hulley SB. Estimating sample size and power. In: Hulley SB, Cummings SR, Browner WS, Grady D, Hearst N, Newman TB, editors. Designing Clinical Research: An Epidemiologic Approach. 2nd ed. Philadelphia, PA: Lippincott, Williams and Wilkins; 2001:65-84.

74. Manchikanti L, Singh V, Rivera JJ, et al. Effectiveness of caudal epidural injections in discogram positive and negative chronic low back pain. Pain Physician. 2002;5(1):18-29.

75. Manchikanti L, Pampati V, Rivera JJ, Beyer CD, Damron KS, Barnhill RC. Caudal epidural injections with Sarapin or steroids in chronic low back pain. Pain Physician. 2001;4(4):322-335.

76. Byrod G, Otani K, Brisby H, Rydevik B, Olmarker K. Methylprednisolone reduces the early vascular permeability increase in spinal nerve roots induced by epidural nucleus pulposus application. J Orthop Res. 2000;18(6):983-987.

77. Hayashi N, Weinstein JN, Meller ST, Lee HM, Spratt KF, Gebhart GF. The effect of epidural injection of betamethasone or bupivacaine in a rat model of lumbar radiculopathy. Spine (Phila Pa 1976). 1998;23(8):877-885.

78. Lee HM, Weinstein JN, Meller ST, Hayashi N, Spratt KF, Gebhart GF. The role of steroids and their effects on phospholipase A2: an animal model of radiculopathy. Spine (Phila Pa 1976). 1998; 23(11):1191-1196. 
79. Minamide A, Tamaki T, Hashizume H, Yoshida M, Kawakami M, Hayashi N. Effects of steroids and lipopolysaccharide on spontaneous resorption of herniated intervertebral discs: an experimental study in the rabbit. Spine (Phila Pa 1976). 1998;23(8):870-876.

80. Pasqualucci A, Varrassi G, Braschi A, et al. Epidural local anesthetic plus corticosteroid for the treatment of cervical brachial radicular pain: single injection verus continuous infusion. Clin J Pain. 2007;23(7):551-557.

81. Mao J, Chen LL. Systemic lidocaine for neuropathic pain relief. Pain. 2000;87(1):7-17.

82. Pasqualucci A. Experimental and clinical studies about the preemptive analgesia with local anesthetics. Possible reasons of the failure. Minerva Anestesiol. 1998;64(10):445-457.

83. Tachihara H, Sekiguchi M, Kikuchi S, Konno S. Do corticosteroids produce additional benefit in nerve root infiltration for lumbar disc herniation. Spine (Phila Pa 1976). 2008;33(7):743-747.

84. Sato C, Sakai A, Ikeda Y, Suzuki H, Sakamoto A. The prolonged analgesic effect of epidural ropivacaine in a rat model of neuropathic pain. Anesth Analg. 2008;106(1):313-320.

85. Manchikanti L, Falco FJE, Boswell MV, Hirsch JA. Facts, fallacies, and politics of comparative effectiveness research: part 2. Implications for interventional pain management. Pain Physician. 2010;13(1): E55-E79.

86. Manchikanti L, Falco FJ, Benyamin RM, Helm S 2nd, Parr AT, Hirsch JA. The impact of comparative effectiveness research on interventional pain management: Evolution from Medicare Modernization Act to Patient Protection and Affordable Care Act and the PatientCentered Outcomes Research Institute. Pain Physician. 2011;14(3): E249-E282.

87. Manchikanti L, Falco FJE, Boswell MV, Hirsch JA. Facts, fallacies, and politics of comparative effectiveness research: part 1. Basic considerations. Pain Physician. 2010;13(1):E23-E54.

88. Chou R, Atlas SJ, Loeser JD, Rosenquist RW, Stanos SP. Guideline warfare over interventional therapies for low back pain: can we raise the level of discourse? J Pain. 2011;12(8):833-839.

89. Manchikanti L, Benyamin RM, Falco FJE, Caraway DL, Datta S, Hirsch JA. Guidelines warfare over interventional techniques: Is there a lack of discourse or straw man? Pain Physician. 2012;15(1):E1-E26.

90. Hotopf M. The pragmatic randomized controlled trial. Adv Psychiatr Treat. 2002;8:326-333.

91. Tunis SR, Stryer DB, Clancy CM. Practical clinical trials. Increasing the value of clinical research for decision making in clinical and health policy. JAMA. 2003;290(12):1624-1632.
92. Roland M, Torgerson DJ. What are pragmatic trials? $B M J$ 1998;316(7127):285

93. International Conference on Harmonisation of Technical Requirements for Registration of Pharmaceuticals for Human Use. ICH Harmonised Tripartite Guideline. Choice of Control Group and Related Issues in Clinical Trials E10. July 20, 2000.

94. Iversen T, Solberg T, Romner B, et al. Effect of caudal epidural steroid or saline injection in chronic lumbar radiculopathy: multicentre, blinded, randomised controlled trial. BMJ. 2011;343:d5278.

95. Carette S, Leclaire R, Marcoux S, et al. Epidural corticosteroid injections for sciatica due to herniated nucleus pulposus. $N$ Engl J Med. 1997;336(23):1634-1640.

96. Karppinen J, Malmivaara A, Kurunlahti M, et al. Periradicular infiltration for sciatica: a randomized controlled trial. Spine (Phila Pa 1976) 2001;26(9):1059-1067.

97. Manchikanti L, Giordano J, Fellows B, Hirsch JA. Placebo and nocebo in interventional pain management: a friend or a foe - or simply foes? Pain Physician. 2011;14(2):E157-E175.

98. Smuck M, Levin JH. RE: Manchikanti L, et al. Cervical medial branch blocks for chronic cervical facet joint pain: A randomized double-blind, controlled trial with one-year follow-up. Spine (Phila Pa 1976). 2008;33(17):1813-1820. Spine (Phila PA 1976). 2009;34(10):1116-1117.

99. Ghahreman A, Ferch R, Bogduk N. The efficacy of transforaminal injection of steroids for the treatment of lumbar radicular pain. Pain Med. 2010;11(8):1149-1168.

100. Indahl A, Kaigle AM, Reikeräs O, Holm SH. Interaction between the porcine lumbar intervertebral disc, zygapophysial joints, and paraspinal muscles. Spine (Phila Pa 1976). 1997;22(24):2834-2840.

101. Indahl A, Kaigle A, Reikeräs O, Holm S. Electromyographic response of the porcine multifidus musculature after nerve stimulation. Spine (Phila Pa 1976). 1995;20(24):2652-2658.

102. Pham Dang C, Lelong A, Guilley J, et al. Effect on neurostimulation of injectates used for perineural space expansion before placement of a stimulating catheter: normal saline versus dextrose $5 \%$ in water Reg Anesth Pain Med. 2009;34(5):398-403.

103. Tsui BC, Kropelin B, Ganapathy S, Finucane B. Dextrose 5\% in water: fluid medium maintaining electrical stimulation of peripheral nerve during stimulating catheter placement. Acta Anaesthesiol Scand. 2005;49(10):1562-1565.
Journal of Pain Research

\section{Publish your work in this journal}

The Journal of Pain Research is an international, peer-reviewed, open access, online journal that welcomes laboratory and clinical findings in the fields of pain research and the prevention and management of pain. Original research, reviews, symposium reports, hypothesis formation and commentaries are all considered for publication.

\section{Dovepress}

The manuscript management system is completely online and includes a very quick and fair peer-review system, which is all easy to use. Visit http://www.dovepress.com/testimonials.php to read real quotes from published authors. 